\title{
Accessory tricuspid valve tissue causing obstruction of the ventricular septal defect in tetralogy of Fallot
}

\author{
GIUSEPPE FAGGIAN, CARLA FRESCURA, GAETANO THIENE, UBERTO BORTOLOTTI, \\ ALESSANDRO MAZZUCCO, ROBERT H ANDERSON*
}

From the Departments of Cardiovascular Surgery, Paediatrics, and Pathology, University of Padova Medical School, Padova, Italy; and The Cardiothoracic Institute, Brompton Hospital, London

SUMMARY Among 61 heart specimens of tetralogy of Fallot with or without pulmonary atresia, four presented with an accessory tricuspid valve leaflet. This structure caused partial or almost complete obstruction of the ventricular septal defect. Depending on the morphology, the accessory tissue was classified into "mobile" or "fixed" types.

The "mobile" variety was tethered by long chordae tendineae which permitted a wide excursion of the leaflet through the ventricular septal defect into the left ventricular outflow tract where it represented a potential cause of obstruction. The "fixed" variety was attached to the edges of the defect by short chordae which reduced considerably its movements. This type created a fixed obstruction of the ventricular septal defect without involving the subaortic left ventricular outflow tract. The precise morphology of the accessory tricuspid valve tissue is of considerable surgical significance. When mobile, the tissue must be resected at the time of surgical repair. When fixed it can be used as a suture anchorage during closure of the ventricular septal defect.

In congenital heart malformations presenting with an interventricular shunt, the degree of mixing between the pulmonary and systemic circuits is directly related both to the size of the ventricular septal defect and the presence of an obstruction to ventricular outflow.

In tetralogy of Fallot, the septal defect is usually large because of malalignment of the outlet septum. Restrictive defects have been reported rarely. ${ }^{1-3}$ In such cases the obstruction was usually caused by accessory tricuspid valve leaflets or fibrous valve-like tissue derived from the membranous septum or its remnants.

We have reviewed our anatomical collection of heart specimens with tetralogy, including cases with pulmonary atresia, so as to evaluate the nature, incidence, and surgical significance of such anatomical structures which may restrict the ventricular septal defect.

\footnotetext{
^During the course of this investigation RHA was visiting professor at the University of Padova, supported by the Departments of Pathology, Cardiology, Paediatrics, and Cardiovascular Surgery.

This work was supported in part by a grant from the Consiglio Nazionale delle Ricerche, Rome, Italy, and by Opera "Martino Arrigoni", Belluno, Italy.

Accepted for publication 23 December 1982
}

\section{Material and methods}

All heart specimens of patients with tetralogy of Fallot, including those with pulmonary atresia, collected at the Department of Pathology, University of Padova Medical School, were reviewed. Some of the patients had undergone surgical procedures during life; others $\bar{\sigma}$ had not. In all specimens geometric measurements were performed with particular reference to the size of $\stackrel{\odot}{\circ}$ the ventricular septal defect, the ratio between the $₹$ thickness of the right and left ventricular free walls, 을 and the degree of the aortic overriding.

\section{Results}

Among 61 specimens studied, four $(6 \cdot 6 \%)$ presented $\mathcal{N}_{\omega}$ with accessory valve-like tissue which partially obs- -2 tructed the ventricular septal defect. Three of themo showed a patent pulmonary outflow tract and one had pulmonary atresia (case 2 ).

All hearts showed laevocardia, situs solitus, $\underline{T}$ atrioventricular concordance, and normally related great vessels. Moreover, in all cases both systemic and $\cong$ pulmonary venous drainages and the distribution pat- $\mathbb{Q}$ terns of the coronary arteries were normal. The septalo 
Table Main pathological fundings

\begin{tabular}{|c|c|c|c|c|c|c|c|}
\hline $\begin{array}{l}\text { Case } \\
\text { No. }\end{array}$ & Age (y) & Cause of death & $\begin{array}{l}R V \\
\text { thickness ( } \mathrm{mm})\end{array}$ & $\begin{array}{l}\text { LV } \\
\text { thickness (mm) }\end{array}$ & \multicolumn{2}{|c|}{$\begin{array}{l}\text { VSD diameter (mm) Aortic } \\
\text { and \% of obstructiondextroposition (\%) }\end{array}$} & $\begin{array}{l}\text { Nature of } \\
\text { obstructive lesion }\end{array}$ \\
\hline 1 & 30 & $\begin{array}{l}\text { Multiple cerebral abscesses, } \\
\text { pulmonary tuberculosis }\end{array}$ & 9 & 11 & $\begin{array}{l}16 \\
30 \%\end{array}$ & 50 & $\begin{array}{l}\text { Freely mobile } \\
\text { inverted hammock } \\
\text { (Fig. 1) }\end{array}$ \\
\hline 2 & $3 / 12$ & $\begin{array}{l}\text { Operative death; creation of } \\
\text { Blalock-Taussig shunt }\end{array}$ & 5 & 6 & $\begin{array}{l}16 \\
90 \%\end{array}$ & 60 & $\begin{array}{l}\text { Dysplastic but } \\
\text { mobile hammock }\end{array}$ \\
\hline 3 & 2 & $\begin{array}{l}\text { Cerebral infarction after } \\
\text { repair of tetralogy }\end{array}$ & 7 & 6 & $\begin{array}{l}9 \\
30 \%\end{array}$ & 50 & $\begin{array}{l}\text { Anchored and } \\
\text { paired hammocks } \\
\text { (Fig. 2) }\end{array}$ \\
\hline 4 & 2 & Pneumonia & 11 & 6 & $\begin{array}{l}6 \\
80 \%\end{array}$ & 40 & $\begin{array}{l}\text { Single anchored } \\
\text { hammock (Fig. 3) }\end{array}$ \\
\hline
\end{tabular}

$\mathrm{RV}$, right ventricle; $\mathrm{LV}$, left ventricle; VSD, ventricular septal defect.

defect was of perimembranous malalignment type, typical of tetralogy.

Further details, together with the measurements taken, are given in the Table. The pertinent findings in the four hearts were the accessory tricuspid valve leaflets. These showed two distinct patterns. The first pattern found in cases 1 and 2 was that of an inverted hammock, secured by long chordae tendineae to the medial papillary muscle and the crest of the ventricular septum (Fig. 1). The hammock lesion not only partially obstructed the septal defect (Fig. la), but was free to float into the subaortic outflow tract, pro- ducing obstruction in this region also (Fig. 1b). The obstructing leaflet illustrated is that from case 1 . The structure in case 2 was similar but the leaflet tissue was more dysplastic. The second pattern found in cases 3 and 4 differed in that the accessory leaflet tissue was firmly anchored to the septum and lacked the mobility of the first type. The obstructive lesion was duplicated in case 3 but was a solitary lesion in case 4 (Fig. 2). In both instances the accessory leaflet particularly blocked the septal defect but did not obstruct the subaortic outflow tract from the left ventricle.

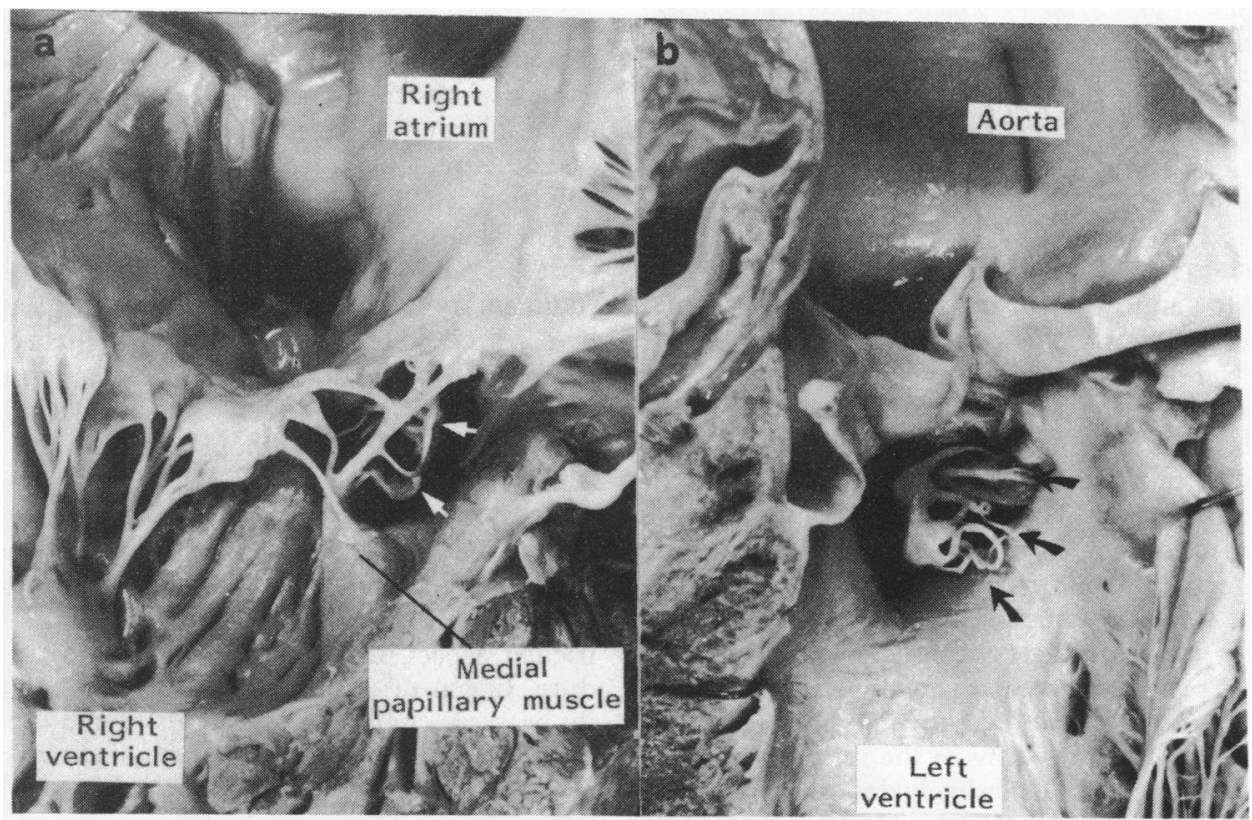

Fig. 1 Case 1. (a) View from the right ventricular inflow. An accessory leaflet (arrows) attached by long well formed chordae tendineae to the medial papillary muscle obstructs the ventricular septal defect. (b) View of the left ventricular outflow: the accessory leaflet is seen to protrude to the left side of the ventricular septal defect, potentially obstructing the left outflow tract. Note some chordae tendineae inserted on the posteroinferior rim of the defect. 


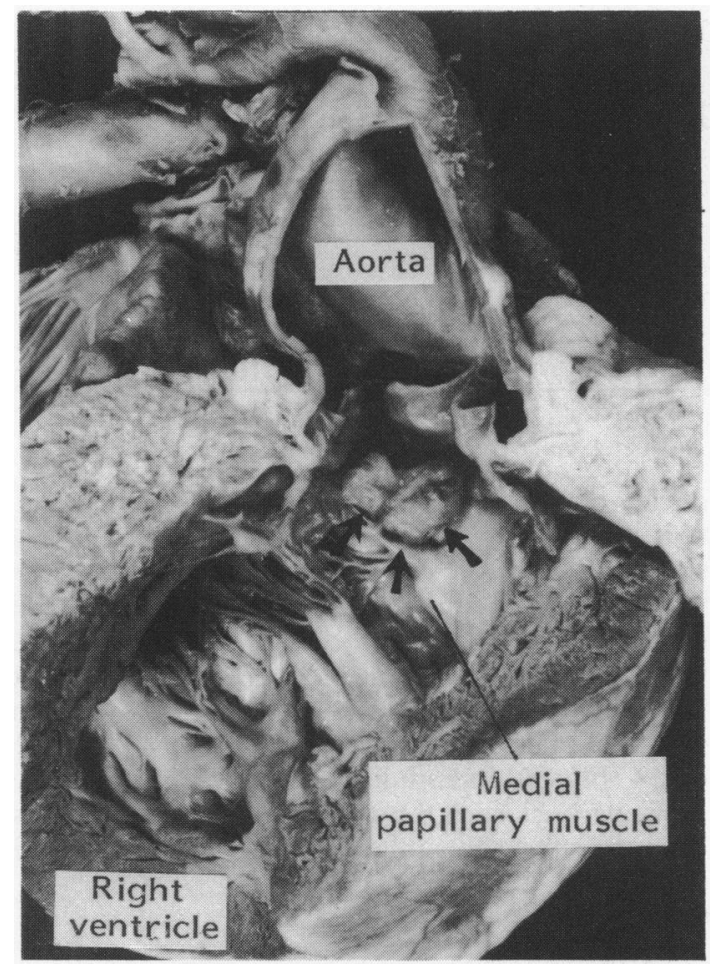

Fig. 2 Case 4. View of the aortic outlet from the right ventricle shows a solitary and fixed polypous fibrous valve-like tag (arrows) which is attached to the crest of the ventricular septal defect and by short chordae tendineae to the medial papillary muscle.

\section{Discussion}

The anatomical features of tetralogy particularly relevant to surgical repair have been well described. ${ }^{4}$ The peculiar morphological lesions described here seem to be relatively rare, though they have been well documented previously. ${ }^{1-3}$ Surprisingly, they were found in one fifteenth of the cases in our cardiopathological collection. They are highly significant from the clinical and haemodynamic standpoint since they may mimic severe pulmonary stenosis or atresia with intact intraventricular septum. Indeed, the accessory valvular tissue originating from the tricuspid valve may during systole almost completely occlude the large ventricular septal defect.

Such accessory tissue tags arising from valvar or fibrous tissue in the environs of the ventricular septal defect have been more extensively described when the defect is isolated, ${ }^{56}$ accompanying complete ${ }^{7}$ or corrected $^{8}$ transposition or is part of an atrioventricular septal defect. ${ }^{6}$

In these other anomalies, the tissue tags have been observed to originate either from the membranous

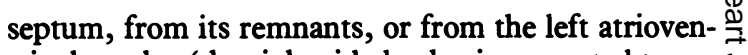
tricular valve (the right sided valve in corrected trans- $c$. position). In contrast, in our cases together with those $\overrightarrow{\vec{F}}$ previously reported in tetralogy, the accessory tags $\stackrel{\circ}{?}$ were always found to originate from the tricuspid $\frac{}{0}$ valve. A single case of corrected transposition with a $\frac{\bar{\sigma}}{\bar{D}}$ tag originating from the left sided morphologically $\frac{\hat{\Phi}}{\widetilde{D}}$ tricuspid valve has also been observed. ${ }^{9}$

The surgical significance of our findings derives from the observation of two discrete morphological $\vec{\circ}$ patterns, not discussed previously to our knowledge and which can be conveniently differentiated as fixed $\vec{\omega}$ and mobile types, respectively.

The mobile type (cases 1 and 2 ) is a large hammock like leaflet anchored to the ventricular septum by long $\overrightarrow{0}$ chordae. This gives it freedom to protrude into the + subaortic region producing a potential cause of left ventricular tract obstruction. Since in tetralogy of Fal- $\vec{\circ}$ lot the ventricular septal defect is also the aortic 단 outflow from the right ventricle, the structure herein $\vec{\square}$ described created also a more or less severe obstruction of the right ventricular outlet to the aorta.

The clinical significance of this feature should not $\vec{\oplus}$ be underestimated, particularly in tetralogy where it $\omega$ may be favoured by the increased right ventricularo pressure and the aortic overriding. In this respect, Sellers and associates ${ }^{6}$ described two cases of isolated ventricular septal defect having tricuspid valve tissue. tags which, from the anatomical point of view, pre- $\frac{\mathbb{Q}}{\mathbb{Q}}$ sented the possibility of left side obstruction. The danger of obstruction, however, in an isolated defect $\frac{0}{3}$ uncomplicated by pulmonary vascular obstructive ${ }_{\supset}$ disease is remote, since the pressure gradient is usu ally from left to right.

The anatomical features of the fixed type of lesion (cases 3 and 4) was the anchoring of the more rudimentary tissue tag to the interventricular septumo by short chordae. The mobility was thus reduced in comparison with the other type. As a consequence, the fixed lesion produced an obstacle which decreased the size of the defect without involving the left ven-음 tricular outflow tract.

From the surgical standpoint it seems wise to resect the mobile variety at the time of the surgical repair, N since it may result in left ventricular outflow tract obstruction if permitted to remain on the left ven 0 N tricular aspect of the patch at the end of the proce- $\omega$ dure. In contrast, the fixed variety need not necessaro ily be excised. It may be left in situ and used as firmo anchorage tissue for the placement of sutures securing the patch.

\section{References}

1 Fischer EA, Thanopoulos BD, Eckner FAO, Hastreiter AR, DuBrow IW. Pulmonary atresia with obstructed 
ventricular septal defect. Pediatr Cardiol 1980; 1: 209-17.

2 Scott O, Macartney FJ, Deverall PB. Anomalous accessory tricuspid valve tissue causing reduction in the size of ventricular septal defect [Abstract]. Eur $\mathcal{f}$ Cardiol 1976; 4: 529.

3 Neufield RH, McGoon DC, DuShane JW, Edwards JE. Tetralogy of Fallot with anomalous tricuspid valve simulating pulmonary stenosis with intact septum. Circulation 1960; 22: 1083-90.

4 Anderson RH, Allwork SP, Ho SY, Lenox CC, Zuberbuhler JR. Surgical anatomy of tetralogy of Fallot. $\mathfrak{F}$ Thorac Cardiovasc Surg 1981; 81: 887-96.

5 Gomes AS, Nath PH, Singh A, et al. Accessory flaplike tissue causing ventricular outflow obstruction. $\mathcal{f}$ Thorac Cardiovasc Surg 1980; 80: 211-6.

6 Sellers RD, Lillehei CW, Edwards JE. Subaortic stenosis caused by anomalies of the atrioventricular valves. $\mathcal{F}$ Thorac Cardiovasc Surg 1964; 48: 289-302.

7 Riemenschneider TA, Goldberg SJ, Ruttenberg HD, Gyepes MT. Subpulmonic obstruction in complete (d) transposition produced by redundant tricuspid tissue. Circulation 1969; 39: 603-9.

8 Levy MJ, Lillehei CW, Elliott LP, Carey LS, Adams $\mathrm{P}$ Jr, Edwards JE. Accessory valvular tissue causing subpulmonary stenosis in corrected transposition of great vessels. Circulation 1963; 27: 494-502.

9 Anderson RH, Becker AE, Gerlis LM. The pulmonary outflow tract in classically corrected transposition. $\mathcal{F}$ Thorac Cardiovasc Surg 1975; 69: 747-57.

Requests for reprints to $\mathrm{Dr} G$ Thiene, Istituto di Anatomia e Istologia Patologica, Via Gabelli 61, 35100 Padova, Italy. 